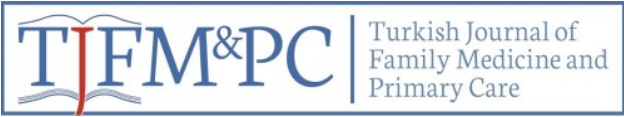

Review Article / Derleme Makale

\title{
Multidisciplinary Team Approach in Diabetes Self Management
}

\section{Diyabet Öz Yönetiminde Çok Disiplinli Ekip Yaklaşımı}

\author{
Arzu Yıldırım $^{*}$, Arif Bayram Hacıhasanoğlu², Nafiz Bozdemir ${ }^{3}$, Rabia Hacıhasanoğlu Aşılar ${ }^{4}$
}

\begin{abstract}
Diabetes is one of the fastest growing globally, serious and costly public health problems associated with significant morbidity and mortality. It is a chronic disease that requires many decisions about complex care activities and self-management that must be done daily by patients. It is important that individuals receive adequate and effective self-management education and support in reducing and delaying complications related to diabetes. Therefore, in order to develop effective diabetes self-management knowledge and skills, it is a necessity to support individuals with interventions carried out especially in primary care under the leadership of family physicians and nurses. In this review, by considering the needs, cultural values, beliefs, education and economic status of the patient, with the multidisciplinary team approach, the main factors in understanding the health and self-management relationship in diabetes with practical, easy and accessible interventions are aimed to be objective and comprehensive offer.
\end{abstract}

Key words: Diabetes; self management; multidisciplinary team approach

\section{ÖZET}

Diyabet, önemli morbidite ve mortalite ile ilişkili olan, küresel boyutta en hızlı artan, ciddi ve maliyeti yüksek halk sağlığı sorunlarından birisidir. Hastalar tarafından günlük olarak yapılması gereken karmaşık bakım faaliyetleri ve öz yönetimle ilgili çok sayıda karar vermeyi gerektiren kronik bir hastalıktır. Diyabetle ilişkili komplikasyonları azaltma ve geciktirmede bireylerin yeterli ve etkili öz yönetim eğitimi ve desteği alması önemlidir. Bu nedenle etkili diyabet öz yönetim bilgi ve becerilerini geliştirmek için diyabeti olan bireylerin özellikle birinci basamakta aile hekimi ve hemşire liderliğinde gerçekleştirilen müdahalelerle desteklenmesi bir gerekliliktir. Bu derlemede çok disiplinli ekip yaklaşımı ile hastanın gereksinimleri, kültürel değerleri, inançları, eğitim ve ekonomik durumu göz önünde bulundurularak, uygulanabilir, kolay ve erişilebilir müdahalelerle diyabette sağlık ve öz yönetim ilişkisinin anlaşılabilirliğinde temel etkenler, objektif ve kapsamlı olarak ortaya koymak amaçlanmıştır.

Anahtar kelimeler: Diyabet, öz yönetim, çok disiplinli ekip yaklaşımı

Received date / Geliş tarihi: 04.03.2020, Accepted date / Kabul tarihi: 25.04.2020

1 Yalova Üniversitesi Sağlık Bilimleri Fakültesi, Hemşirelik Bölümü, Psikiyatri Hemşireliği ABD, Yalova-TÜRKIYE.

${ }^{2}$ Bursa Yüksek İhtisas Eğitim ve Araştırma Hastanesi, Endokrinoloji ve Metabolizma Hastalıkları, Bursa-TÜRKIYE.

${ }^{3}$ Çukurova Üniversitesi Tıp Fakültesi, Dahili Tıp Bilimleri Bölümü, Aile Hekimliği ABD, Adana-TÜRKIYYE.

${ }^{4}$ Yalova Üniversitesi Sağlık Bilimleri Fakültesi, Hemşirelik Bölümü, Halk Sağlığı Hemşireliği ABD, Yalova-TÜRKIYE.

*Address for Correspondence / Yazışma Adresi: Arzu Yıldırım, Yalova Üniversitesi Sağlık Bilimleri Fakültesi, Hemşirelik Bölümü, Psikiyatri Hemşireliği ABD, Yalova-TÜRKIYYE.

E-mail: yildirimarzu25@hotmail.com

Yıldııım ve ark. Diyabet Öz Yönetiminde Çok Disiplinli Ekip Yaklaşımı. TJFMPC, 2020;14(3): 479-491.

DOI: $10.21763 /$ tjfmpc.698927 


\section{GíRiş}

Diabetes mellitus (DM), büyük ölçüde şişmanlık, sağlıksız beslenme alışkanlıkları ve hareketsiz yaşam biçiminden kaynaklanan ${ }^{1}$, uygun şekilde yönetilmediğinde ciddi komplikasyonları olan ${ }^{2}$, yüksek kan şekeri düzeyi ile belirli ${ }^{3}$, ciddi ve oldukça yaygın metabolik bir hastalıktır., ${ }^{1,3}$ Kültürel, sosyodemografik ve coğrafi sınırları aşan ${ }^{4}$, yüksek engellilik ve ölüm oranına neden olan, ekonomi ve toplumun sürdürülebilir kalkınmasını etkileyen ciddi bir halk sağlığı sorunudur ve topluma ağır bir hastalık yükü getirmektedir. ${ }^{5}$ Diyabet, 21. yüzyılın en hızlı artan sağlık sorunlarından biridir ve diyabetle yaşayan yetişkinlerin sayısı son 20 yılda üç kattan fazla artmıştır. Uluslararası Diyabet Federasyonu 9. Diyabet Atlas1 son basım1, günümüzde 463 milyon bireyin diyabeti olduğunu bildirmektedir. ${ }^{6}$ Bu rakamların 2045 yılına kadar 693 milyona yükselebileceği, diyabetle yaşayan bireylerin yaklaşık yarısına $(\% 49,7)$ tanı konulmadığı ve 2017 yılında yaklaşık 5 milyon ölümün 20-99 yaş aralığında diyabet kaynaklı olabileceği bildirilmektedir. ${ }^{3}$ Türkiye'de 26.499 birey ile kesitsel toplum temelli olarak yapılan Türkiye Diyabet Epidemiyolojisi II (TURDEP II, 2013) çalışmasına göre, 20 yaş ve üzeri nüfusta diyabet prevalansı $\% 13,7$ olarak belirlenmiştir. ${ }^{7}$

Etkili müdahaleler ve yaşam biçimi değişiklikleri ile diyabetli veya diyabet riski olan bireylerin sağlı sonuçları iyileştirebilir. Günümüzde Tip 1 diyabetin (T1DM) önlenmesinde etkili ve güvenli bir müdahale mevcut değildir. Bununla birlikte, çocuklarda yüksek büyüme oranının olası bir risk faktörü olduğuna dair bazı kanıtlar bulunup, bu da aşırı yemek yemeyi ve sedanter yaşam biçimini önleyen sağlıklı bir yaşam biçiminin önerildiğini göstermektedir. Sağlıklı beslenme ve fiziksel olarak aktif bir yaşam biçimi Tip 2 diyabet (T2DM) riski taşıyan insanlar için en önemli önleyici faktörlerdir. Son yirmi yılda yapılan klinik çalışmalar, T2DM'nin önlenmesi veya gecikmesinin, yaşam biçimi değişiklikleri ve bazı farmakolojik ajanların uygulanması ile mümkün olduğunu açıkça göstermektedir. Son kanıtlar, T2DM remisyonunun mümkün olabileceğini öne sürmesine rağmen, hem T1DM hem de T2DM'nin günümüzde sürekli öz yönetim gerektiren yaşam boyu devam eden durumlar olarak kabul edilmesi gerektiğini göstermektedir. ${ }^{6}$

Amerikan Diyabet Derneği ve Avrupa Diyabet Araştırmaları Derneği, yetişkinlerde T2DM yönetimine ilişkin 2012-2015 yıllarında yayınlanan önceki durum bildirimlerini güncellemek için bir uzlaşı raporu yayınlamıştır. Bu raporda literatürün 2014 yılından bu yana sistematik olarak değerlendirilmesi ile, yaşam biçimi yönetimi ve diyabet öz yönetimi eğitimi ve desteğine ilave odaklanmayı kapsayan yeni öneriler sunulmuştur. T2DM tedavisinin amaçlarının komplikasyonları önleme veya geciktirme ve yaşam kalitesini sürdürme olduğu; bunun da kan şekeri kontrolü ve kardiyovasküler risk faktörü yönetimini, düzenli takibi ve daha önemlisi, öz bakım aktivitelerinde hasta katılımını arttırmada hasta merkezli yaklaşımı gerektirdiği üzerinde durulmuştur. Ayrıca tıbbi beslenme tedavisi (TBT), fiziksel aktivite, kilo verme, sigara bırakma danışmanlığı ve genellikle diyabet öz yönetim eğitimi (DÖYE) ve diyabet öz yönetim desteği (DÖYD) bağlamında sunulan ruhsal destek dahil olmak üzere yaşam biçimi yönetiminin, diyabet bakımının temel yönleri olduğu vurgulanmıştır. ${ }^{8}$ Hastalar, hastalığın ilerlemesini kontrol etmek için yaşam boyu tedaviye, kan şekerini düzenleyici ilaçlara ve yaşam biçimi düzenlemelerine gereksinim duyarlar. Ayrıca diyabet, hasta ve ailelerinin hastalığın kendi kendine izlemi ve yönetimini gerçekleştirme yeteneğine sahip olmasını gerektiren, uzun ve tekrarlayan özelliklere sahiptir. Bu nedenle, diyabet hastalarının öz yönetim düzeyini arttırmanın uygun yollarını bulmak, çok önemli ve anlamlıdır. ${ }^{5}$ Diyabetin gelişimi ve iyileştirilmesi yaşam biçimi ile ilişkili olduğundan hastanın davranışı ve güçlendirilmesi, hastalığın yönetiminde önemlidir. ${ }^{2}$ Etkili hasta ve hastalık öz yönetimi hastanın güçlendirilmesine, benlik saygısını ve iyilik halini arttırmaya yardımcı olabilmektedir.9 Amerikan Diyabet Derneği ve Avrupa Diyabet Araştırmaları Derneği çalışmaları, obez bireyler için yaşam biçimi, ilaç ve cerrahi müdahaleler dâhil olmak üzere, kilo vermeyi hedefleyen çabalar önermektedir. ${ }^{8}$

\section{Öz yönetim}

Öz yönetim, modern sağlık sistemlerinin önemli bir özelliği olarak nitelendirilmekte ${ }^{10}$ ve bireyin davranışlarını ve iyilik halini iyileştirme hedefleriyle öz bakım faaliyetlerine etkin olarak katılma süreci olarak tanımlanmaktadır. ${ }^{11}$ Öz yönetim; kişinin ne yiyeceğine, egzersiz yapıp yapmayacağına, kontrole gidecekse bunu ne zaman yapacağına veya ilacını ne zaman alacağına karar vermesidir. ${ }^{12}$ Kendini yönetme kişinin kronik durumunun etkilerini önlemek, kontrol etmek veya azaltmak için yaptığı veya yapmadığı günlük görevleri ifade eder. Herkes kendini yönetir; sorun, kişilerin sağlık ile ilgili davranışlarını ve klinik sonuçlarını iyileştiren kararları verip vermemesidir.

Kronik hastalığg olan bireylerin öz yönetimi desteklemesi, birçok ülkede kronik hastalıklarla ilişkili hastalık yükü ve sağlık hizmeti kullanımının azaltılmasında önemli olarak kabul edilmektedir. ${ }^{10}$ Diyabet yönetimi çoğunlukla hastalar ve aileler tarafından gerçekleştirildiğinden, öz yönetim diyabet bakımının temelidir. ${ }^{11}$ Öz yönetim başarısı, üç düzeyde birbirinden karşılıklı olarak 
etkilenmektedir: a) Bireylerin eğilimleri ve yeteneklerine göre mikro düzeyde, b) Aile, işyeri, okul ve sağlık kuruluşunda maddi koşullar, ilişkiler ve rollere göre orta düzeyde, c) Genel ekonomik koşullar, kültürel normlar, beklentiler ve sağlık sisteminin temel mantığı ile makro düzeyde etkilenir. ${ }^{13}$

Öz yönetim yemek ve fiziksel aktivite planlama, kan şekeri izlemi, diyabet ilaçlarını alma, hastalık atakları ve düşük/yüksek kan şekeri ataklarını yönetmeyi içerir. ${ }^{11}$ Kan şekeri düzenli öz izlemi, özellikle insülin alan bireylerde öz yönetim ve ilaca uyum konusunda yardımcı olup, bu izlem planları bireyselleştirilmelidir. Diyabetli bireyler ve sağlık bakım ekibi, verileri etkili ve zamanında kullanmalıdır. Bununla birlikte, bazı bireylerde kan şekeri izlemi, özellikle eğitim ve destekle birleştirildiğinde yaşam biçimi ve ilaç yönetiminin kan şekeri ve semptomları üzerindeki etkisine ilişkin içgörü sağlayabilmektedir. ${ }^{8}$ Öz yönetim tedavi planları doktor, hemşire, diyetisyen ve eczacı gibi çeşitli sağlık profesyonelleri ile iletişim halinde bireysel olarak geliştirilmektedir. ${ }^{11}$ Günümüzde diyabetli bireylerin yaklaşık \%50'sinin, glikozillenmiş hemoglobin (HbAlc) için önerilen $<\% 7,0$ hedefine ulaşmadığı ve sürdürmediği ve bu bireylerin yalnızca \%14,3'ünün HbA1c, kan basınc1, düşük yoğunluklu lipoprotein, kolesterol ve sigara içmemede belirlenen hedeflerde olduğu tahmin edilmektedir. ${ }^{14,15}$ Hastaların önemli bir kısmı öz yönetimi gerçekleştirmede başarısız olmaktadır. ${ }^{11}$ Olumsuz tutumlar, başa çıkma zorlukları ve depresyon, anksiyete ve yeme bozuklukları gibi ruhsal sorunlar diyabette yaygındır ve kötü hasta sonuçlarına yol açabilmektedir. ${ }^{16}$ Suudi Arabistan'da T2DM hastalarında öz yönetim aktivitelerinin sıklığını belirlemek amacıyla yapılan bir çalışmada, hastaların yalnızca \%15'inde iyi glisemik kontrol (HbAlc $\leq 7 \mathrm{mmol} / \mathrm{L})$ belirlenmiştir. Hastaların birçoğunun ilaçlarını reçete edildiği şekilde aldığı, ancak diğer öz yönetim uygulamalarına düşük düzeyde uyum gösterdikleri (genel olarak haftada ortalama 3,7 gün), ayrıca erkeklerin ve düşük gelirli olanların öz yönetim faaliyetlerini uygulama olasılıklarının daha düşük olduğu tespit edilmiştir. ${ }^{17}$ Sistematik bir incelemede de diyabet tanısı konan bireylerin öz yönetim aktivitelerini, bu aktivitelerin kullanım sıklıklarını ve öz yönetim uygulamalarının zaman içinde değişip değişmediğini belirlemek için 32 çalışma değerlendirilmiştir. Çalışma sonucu, diyabetli bireylerin düzenli öz yönetim etkinliklerini yürüttüğünü ve ilaca uyumlarının yüksek olduğunu göstermiştir. Ancak kan şekeri testi, diyet, fiziksel aktivite ve ayak bakımı yönünden uyumun değiştiği, fiziksel aktivite düzeylerinin ise zamanla değişmediği belirlenmiştir. Ayrıca kanıtlar, diyabeti olan bazı bireylerin, tatil gibi özel durumlarda öz yönetim uygulamalarını değiştirdiğini göstermiştir. Uygulayıcılar için çıkarımlar olarak, sağlık profesyonellerinin diyabet öz yönetiminin önemi ve düzenli öz bakıma uyum konularında farkındalığı arttırmada sürekli çaba sarf etmeleri gerektiği vurgulanmıştır. ${ }^{18}$ Birleşik Krallık, Hollanda, Norveç, İspanya, Bulgaristan ve Yunanistan sağlık sistemlerinde yer alan diyabet öz yönetimi düzenlemeleri ile ilgili nicel literatürü tanımlamayı ve bunların nasıl entegre edildiğini araştırmayı amaçlayan bir derlemede, DM öz yönetiminin fiziksel, entelektüel, duygusal ve sosyal olarak zorlayıcı olduğu, bu nedenle bazı hastaların bireysel kaynaklar (sağlık okuryazarlığı, direnç vb.) ya da bireysel, ailevi ve toplumsal koşullar karşısında bunaltıcı olması nedeniyle öz yönetim ile ilgilenmedikleri ortaya koyulmuştur. Ayrıca girişimsel çalışmaların çoğunun birinci basamak hizmetlerde (aile hekimi ve hemşire) hasta merkezli diyabet öz yönetimi odaklı olduğu, diyabet uzmanı hemşirelerin profesyonel rolünün, çok disiplinli yaklaşımlara olan gereksinimin ve hasta eğitimine odaklanmanın, ilgili programların tasarımında temel ilkeler olarak ortaya çıktığı gösterilmiştir. ${ }^{9}$

\section{Diyabet öz yönetim davranışları}

Mevcut k1lavuzlar, prediyabet ve diyabetli birçok hasta için vücut ağırlığının \%5-7'si arasında uzun vadeli kilo kaybı ve haftada en az 150 dakika, en az orta yoğunlukta fiziksel aktivite önermektedir. ${ }^{19}$ Amerikan Diyabet Eğitimcileri Derneği (AADE), diyabet öz yönetim davranışlarıyla ilgili yedi temel davranışı hastalığın öz yönetiminde kilit davranışlar olarak tanımlamıştır. Bu davranışlar: fiziksel aktivite, sağlıklı beslenme, ilaç alma, diyabet kontrol göstergelerinin izlenmesi (kan şekeri ve HbA1c), diyabetle ilgili komplikasyon riskini azaltma, problem çözme ve ruhsal toplumsal uyumu içerir. ${ }^{16,18}$ AADE tarafından diyabet öz yönetimi sonuçları için kapsamlı bir çerçeve, temelde yedi öz bakım davranışı ile geliştirilmiştir. Diyabet Öz Yönetim Sonuç Çerçevesi (DÖYSÇ)'nin unsurları Şekil 1'de gösterilmiştir. Program formu üç unsurdan oluşmaktadır: Program içeriği, program özellikleri ve daha fazla sınıflandırılmış katılımcı özellikleri. İlk sonuç unsurları, öz yeterlik ve farkındalık gibi on bireysel yatkınlıktan; ikinci sonuç unsurları, yedi AADE davranış kategorisinden oluşmakta ve üçüncü sonuç unsurları ise hastalık sonuçları ve ruhsal eş tanı gibi sağlıkla ilişkilendirilmektedir. ${ }^{20}$ 

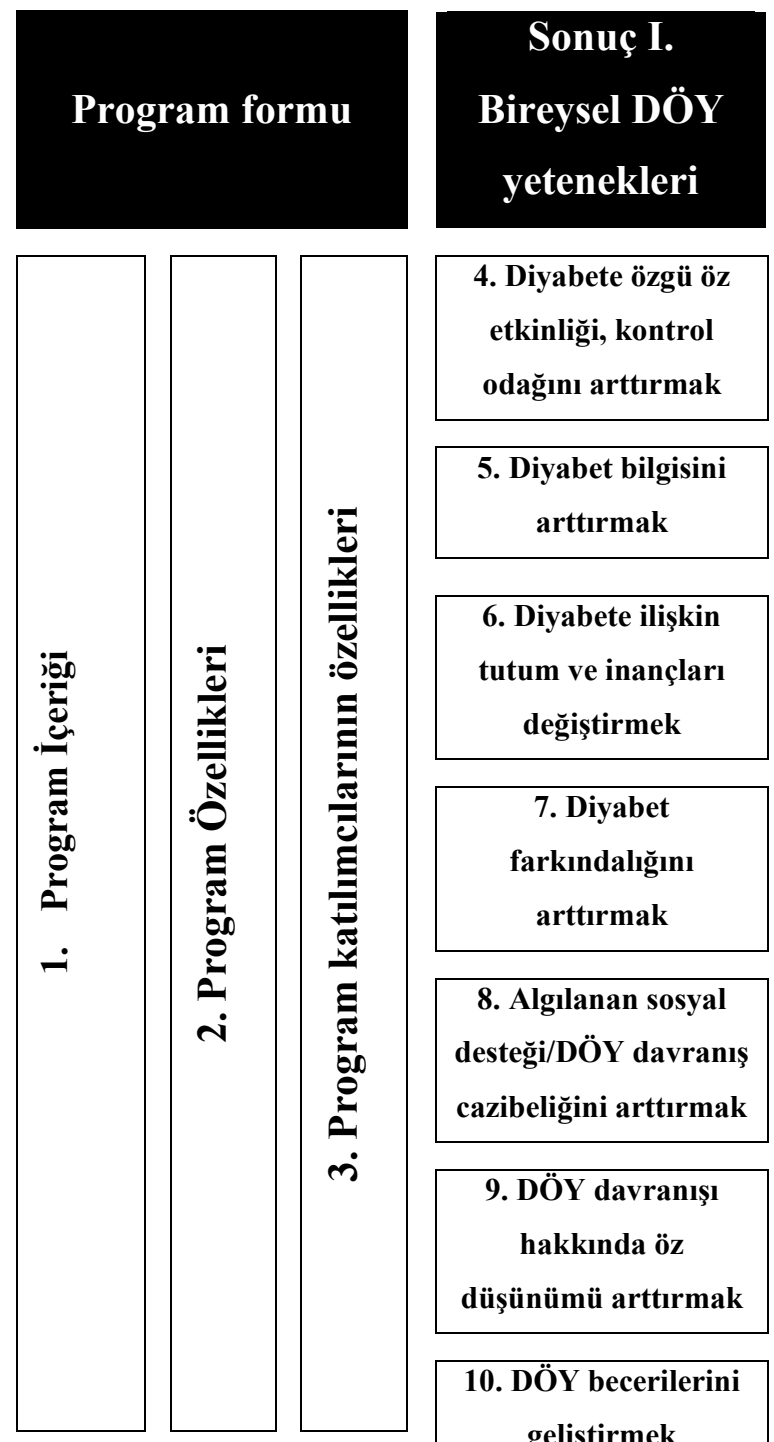
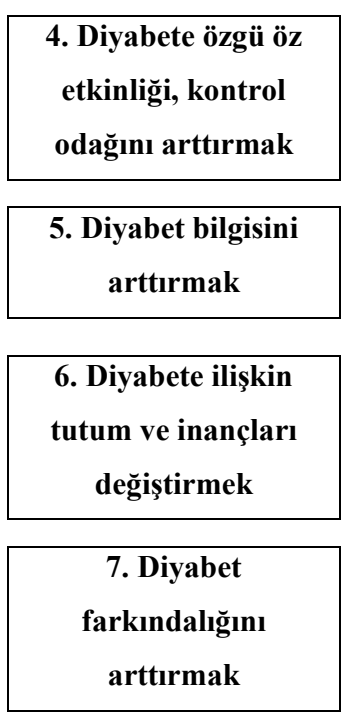

\section{Algilanan sosyal desteği/DÖY davranış cazibeliğini arttırmak}

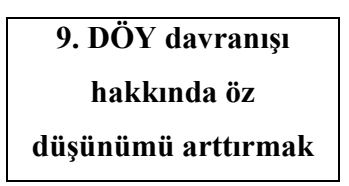

10. DÖY becerilerini

geliştirmek
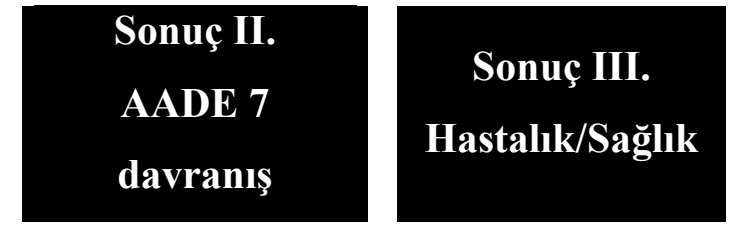

11. Sağlıklı beslenme
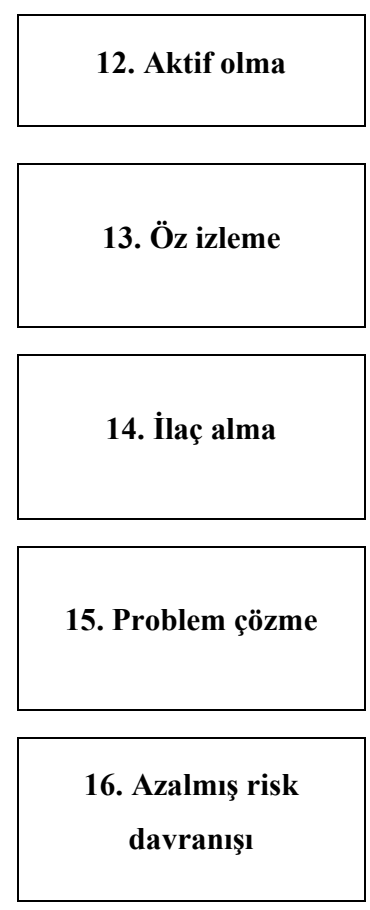

20. Sağlıkla ilişkili yaşam kalitesi

21. Ruhsal eştanı

18. Hastalıkla ilişsili

sonuçlar

19. Azalmış sağlık

riskleri

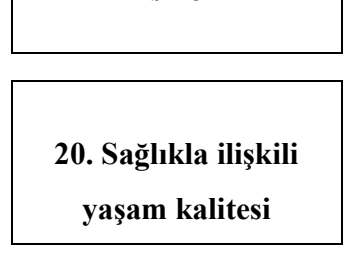

Şekil 1. Diyabet Öz Yönetim Sonuç Çerçevesi (DÖYSÇ) unsurları ve alt alanları

(S Van den Broucke, GH Van der Zanden and the Diabetes Literacy consortium. Diabetes literacy. Enhancing the effectiveness of diabetes self-management education. Final report. Louvain-la-Neuve: Université catholique de Louvain, 2016, izin alınmıştır).

\section{Diyabet öz yönetim eğitimi}

Eğitim, sağlı̆̆ı geliştirme ve hastalı̆̆ın önlenmesinde yapılan müdahalelerin kilit bir bileşenidir. Diyabet eğitimi bireylerin hastalı̆̆ ve tedavisini anlamalarına, davranışlarını sağlık durumlarına göre değerlendirmelerine, düzenlemelerine ve değiş̧irmelerine, hastalıklarını etkin bir şekilde yönetmeleri ve yaşam kalitelerini iyileştirmeleri için gereken becerileri geliştirmelerine yardımcı olur. ${ }^{16}$ Amerikan Klinik Endokrinologlar Birliği ve Amerikan Diyabet Derneği Bakım Standartları (2015) DÖYE'yi çoklu ilacı ve dozaj algoritmasını içerebilen farmakoterapi ile uyum içinde, diyabeti olan bireylerin bakımının ayrılmaz bir parçası olarak kabul etmektedir. ${ }^{15}$ DÖYE, diyabetin başarılı bir şekilde öz yönetimi için gerekli olan bilgi, beceri ve yeteneklerin geliştirilmesini kolaylaştırmaya yönelik işbirlikçi ve devam eden bir süreç olarak tanımlamaktadır. ${ }^{21}$

Bireylerin etkili bir şekilde öz yönetimleri için gereken becerileri öğrenmelerinde DÖYE, eğitim sırasında edinilen kazanımları devam ettirmede destek sağlayarak hastalıkla başa çıkma temelinde kritik öneme sahiptir. DÖYE'nin genel amaçları bilgiye dayalı karar vermeyi, öz bakım davranışlarını, problem çözmeyi ve sağlık ekibi ile aktif iş birliğini desteklemek ve klinik sonuçları, sağlık durumunu ve yaşam kalitesini iyileştirmektir. ${ }^{22}$ DÖYE, en iyi glisemik kontrolü sağlamada tıbbi yönetime ek olarak, hastalığı etkin bir şekilde yönetebilmeleri için bireylerin gereksinim duyduğu bilgi ve becerileri sağlar. Yol gösterici ilkelerce düzenlenen DÖYE, klinik sonuçları ve yaşam kalitesini iyileştirmede etkili 
olup, kuramsal temelli güçlendirilmiş modellerden geliştirilmiştir. "En iyi" eğitim yaklaşımı olmamasına rağmen, davranışsal ve ruhsal toplumsal stratejiler içeren kültüre ve yaşa uygun programlar, hasta sonuçlarında iyileşme göstermektedir. ${ }^{23}$

\section{Diyabet öz yönetim desteği}

Öz yönetim başarı kanıtı, davranış değişikliğinde birey merkezli sonuçlara odaklanmakla birlikte öz yönetim desteği, ulusal ve küresel olarak kronik hastalık yönetiminin merkezi bir yönünü oluşturmaktadır. ${ }^{13}$ DÖYD, prediyabet veya diyabet tanısı konan kişiyi, kendi durumunu yönetmek için gerekli davranışları uygulama ve sürdürmede resmi öz yönetim eğitiminin dışında veya ötesinde bireyi sürekli olarak destekleyen etkinliklerden oluşmaktadır. ${ }^{4}$ Devam eden DÖYD, diyabetli bireye durumunu sürekli olarak yönetmesi için gereken davranışları uygulama ve sürdürmede yardımcı olan aktivitelerdir. ${ }^{22}$ Sağlanan desteğin türü davranışsal, eğitimsel, ruhsal toplumsal veya klinik olabilir. ${ }^{4}$ Carpenter ve arkadaşları (2018) tarafından T2DM'li hastalarda diyabet öz yönetimini destekleyen girişimleri değerlendirmek amacıyla, girişimsel çalışmaların kapsamlı yöntem bilimsel yaklaşımla bütünleyici inceleme tasarımında yapılan bir derleme çalışmasında, çok çeşitli kültür ve etnik kökene sahip 17 ülkeden çalışmalar incelenmiştir. İncelenen çalışmalarda girişim kategorileri: motivasyonel görüşme, koçluk/akran sağlığ1 koçluğu/akran desteği, problem çözme terapisi, teknoloji temelli girişimler, yaşam biçimi değişikliğ programları, hasta eğitimi, farkındalık ve bilişsel davranışçı terapi olarak belirlenmiştir. Müdahaleler tüm girişimsel gruplarda karışık sonuçlar vermiş olsa da, birçok çalışma fizyolojik, davranışsal ve psikolojik sonuç ölçütlerinde az, ılımlı iyileştirmeleri desteklemiştir. Genel olarak yapılan müdahaleler, glisemik kontrolde kısa süreli iyileşmeler göstermiş, bilgiyi ve öz etkililiği arttırmada, sıkıntıyı azaltmada etkili olmuştur. Müdahalelerin dikkate değer ölçüde heterojen olduğu gösterilmiştir. En sik bildirilen fizyolojik ölçüm HbA1c düzeyi olup, sonuç ölçütleri çoğunlukla 6 ve 12 ayda toplanmış ve çoğu araştırmanın süresi bir yılla sınırlı kalmıştır. ${ }^{11}$ Diyabetli bireylerin etkili diyabet öz yönetimi uygulamaları ve davranışlarına sürekli katılmaları konusunda bilgilendirilmeleri ve motive edilmeleri için fursatları geliştirme, DÖYE ve DÖYD'nin amaçları olarak belirtilmektedir. Ayrıca DÖYD, DÖYE ile birleştiğinde tamamlayıcı olmakta, hastalar etkili öz yönetim için gereken temel becerileri öğrenmekte ve DÖYE ile görülen kısa vadeli faydaları sürdürmektedir. Giderek artan bir araştırma kanıtı, DÖYE ve DÖYD birleşiminin glisemik kontrol, öz etkililik, öz bakım davranışları (kan şekeri ve sağlıklı beslenme izlemi), diyabet sıkıntısı ve ayak komplikasyonlarını azaltmada en avantajlı olduğunu göstermektedir. Bu doğrultuda en etkili davranışsal müdahaleler hasta merkezli bir yaklaşım, paylaşımlı karar alma, problem çözme becerilerinin geliştirilmesi ve hasta tarafindan belirlenen hedeflere yönelik eylem planlarının kullanımını içermektedir (Şekil 2). ${ }^{24}$ Paylaşımlı karar alma, hasta merkezli bakımın anahtar bileşeni olup, hasta bakış açısını ve önceliklerini ortaya çıkarmak ve hastaların daha aktif bir şekilde bakıma katılabilmeleri için seçenekler ve bilgiler sunmaktır. $^{22}$

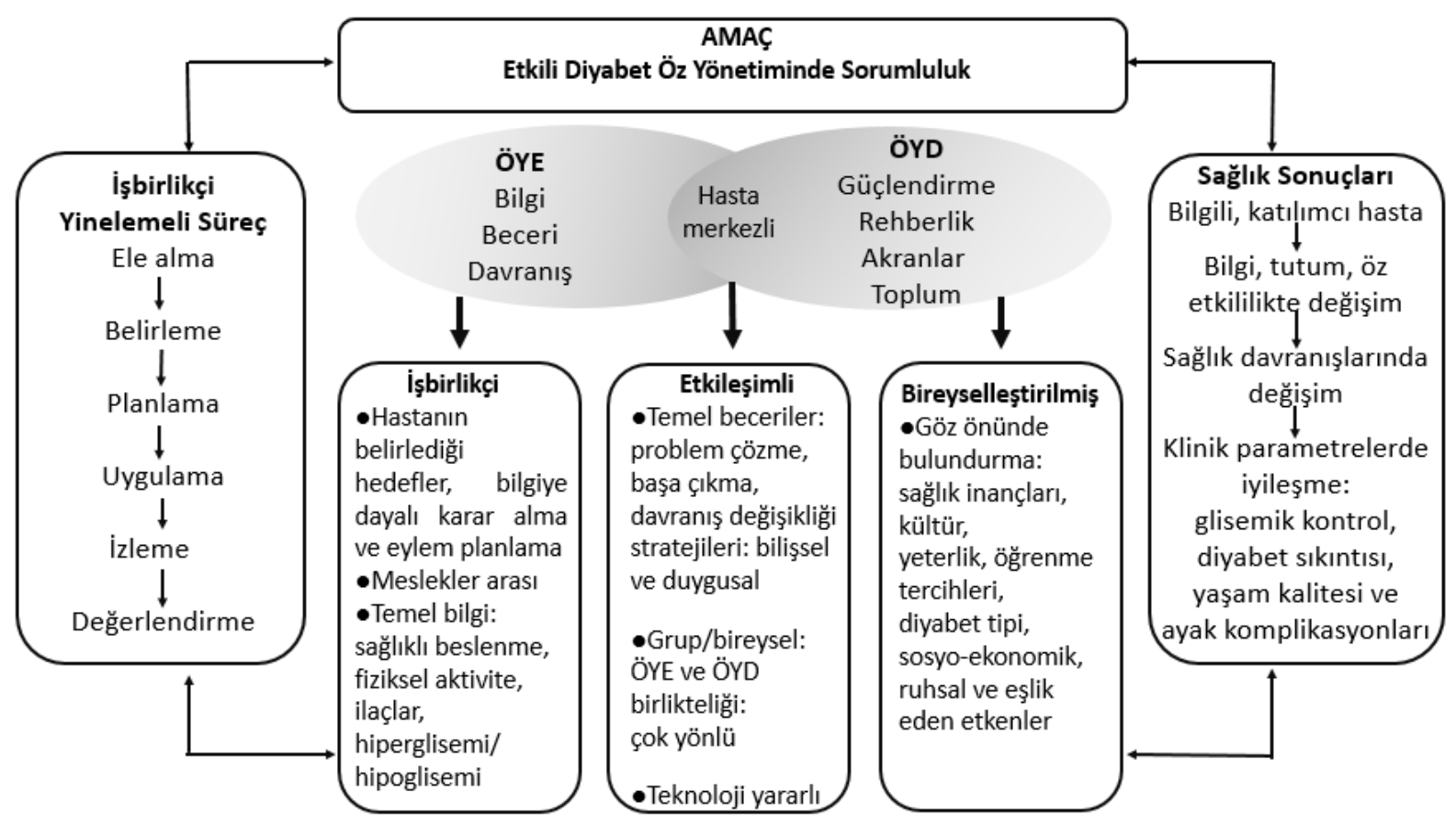


Şekil 2. Öz-Yönetim Eğitimi (ÖYE) Ve Öz-Yönetim Desteği (ÖYD) modeli

(Sherifali D, Berard LD, Gucciardi E, MacDonald B, MacNeill G. Self-Management Education and Support. Diabetes_Canada_Clinical Practice Guidelines_Expert_Committee. Can J_Diabetes. 2018;42 Suppl 1:S36-S41, izin alınmıştır).

Hasta merkezli yaklaşım, DÖYE/DÖYD'de, mevcut ve gelecekteki gereksinimler için temel sağlar. Devam eden DÖYE/DÖYD, kişinin tedavi ve yaşam geçişleri sürecindeki değişiklikleri kolaylaştırmak için engellerin üstesinden gelmesine ve devam eden taleplerle başa çıkmasına yardımcı olabilir. ${ }^{22}$ İranlı T2DM'li erişkinlerde davranışsal müdahalelerin öz yönetim üzerindeki etkinliğini belirlemek için 12 randomize kontrollü, 11 yarı deneysel türde yürütülen çalışmaların sistematik inceleme ve meta analiz çalışmasında, kontrol grubu ile karşılaştırıldığında, davranışsal müdahalelerin HbA1c $(\% 0,61)$ düzeyini anlamlı olarak düşürdüğü, yanı sıra kan şekeri, lipid profilleri, bilgi, tutum, uygulama, öz etkililik, yaşam kalitesi ve öz bakımın iyileştirilmesinde etkili olduğu bildirilmiştir. Ayrıca daha uzun süreli, yüksek yoğunluklu ve çok disiplinli ekip tarafindan sunulan grup müdahalelerinde, daha etkili sonuçlarla karşılaşılmıştır. ${ }^{25}$

\section{Öz yönetim eğitimi ve desteği sağlayıcıları}

Öz yönetim desteği, karar desteği, dağıtım sistemi tasarımı, klinik bilgi sistemleri ve toplum kaynakları ve politikalarını içeren koordineli bir kronik bakım modeli, daha güçlü hastalar ve daha iyi hazırlanmış etkin sağlık ekipleri arasındaki etkileşimi geliştirir. ${ }^{8}$ Diyabetli bireylerin bakımlarında etkin bir rol üstlenen işbirlikçi ve bütünleyici ekip yaklaşımı çok önemlidir. Hastalı̆̆ın etkili bir şekilde yönetilmesini sağlamak için, çok disiplinli ekip yaklaşımları gereklidir ve ekip yaklaşımı, bilgili ve ilgili bir hasta ile etkin bir ekip arasında iyi kurulmuş bir ilişkiye dayanmalıdır. ${ }^{26}$

\footnotetext{
Bazen klinik tembellik olarak da belirtilen terapötik tembellik, tedavi hedeflerine ulaşılmadığında tedaviyi güçlendirmede başarısızlık olarak ifade edilmektedir. Terapötik tembelliğin nedenleri sağlik profesyonelleri, hasta ve/veya sağlık sistemi düzeyinde olup, çok etkenlidir. Parçalanmış bir sağlık sistemi, terapötik tembelliğin gelişmesine katkıda bulunabilmekte ve hasta merkezli bakımın sunumunu engelleyebilmektedir. Terapötik tembelliği hedefleyen müdahaleler, glisemik kontrolün iyileşmesini ve zamanında insülin tedavisinin yoğunlaştırılmasını kolaylaştırmakta, hemşire veya eczacıları içeren çok disiplinli ekipler, terapötik tembelliği azaltmaya yardımcı olabilmektedirler. ${ }^{8}$ Cani ve arkadaşları (2015) tarafından Brezilya'da bir eğitim hastanesinde insülin tedavisi gören T2DM'li hastalarda klinik eczacılık programının, sağlık sonuçları üzerindeki etkisini değerlendirmek
}

amacıyla randomize kontrollü bir çalışma yürütülmüştür. Girişim grubundaki $(n=34)$ hastalar bireyselleştirilmiş farmakoterapötik bakım planı ve diyabet eğitimi alırken, kontrol grubundaki hastalar $(n=36)$ standart bakım almıştır. Müdahale sonucunda girişim grubunda diyabet ve ilaç bilgisi ile birlikte ilaca uyum artmış, doğru insülin enjeksiyonu ve evde kan şekeri izleme teknikleri gelişmiş, HbA1c değerleri iyileşmiş; kontrol grubunda ise herhangi bir değişme olmamıştır. Ayrıca diyabetle ilişkili yaşam kalitesinin, girişim grubunda iyileştiği, kontrol grubunda ise belirgin şekilde kötüleşme gösterdiği rapor edilmiştir. ${ }^{26}$ Etkili bir diyabet yönetimi hizmetinde sorumluluğu olan çok disiplinli ekip üyelerinin, öncelikle tıbbi yönetimle birlikte DÖYE'nin hasta sonuçlarını iyileştirdiği konusunda bilgili ve duyarlı olması gerekmektedir. Türkiye'de sağlık çalışanlarına yönelik web tabanlı bir T2DM programının geliştirilmesi amacıyla metodolojik ve ön test-son test tek gruplu yarı deneysel türde yapılan pilot bir çalışmada, 20 hemşireye yönelik Kemp Öğretim Tasarımı Modeli doğrultusunda geliştirilen Web Tabanlı Diyabet Eğitim Programı uygulanmıştır. Program sonucunda hemşirelerin T2DM bilgilerinin arttığı, programı başarılı ve yararlı buldukları bildirilmiştir. $^{27}$ İngiltere'de yarı yapılandırılmış görüşmelerle, sağlık çalışanlarının öz yönetim konusundaki görüşlerini DÖYE bağlamında daha özel olarak incelemek amacıyla nitel bir çalışma yürütülmüştür. Birinci basamak hizmeti uygulayıcıları (aile hekimi), uygulama hemşireleri, diyabet uzmanı hemşireler, sağlık görevlileri, danışma ve bakım görevlileri olmak üzere 22 sağlık profesyonelinin görüşleri analiz edilmiştir. Görüşmelerde sağlık çalışanları diyabet bakımında öz yönetim yaklaşımını temelde gerekli ve değerli olarak ifade etmişler, ancak bazı hastalarda öz yönetimi teşvik etme konusunda çelişkili duygular belirtmişlerdir. Ayrıca çalışanlar arasında DÖYE'nin içeriği ve hastaya yararları konusunda farkındalık eksikliği olduğu belirlenmiştir. ${ }^{10}$

Chrvala ve arkadaşları (2016) tarafindan T2DM'li bireylerin bilgi, beceri ve öz yönetim faaliyetlerini gerçekleştirme becerisini ve hedef belirleme konusunda bilgiye dayalı karar vermeyi geliştirmeye yönelik unsurları içeren 118 randomize kontrollü çalışmayı sistematik olarak inceleyen bir derleme çalışması yapılmıştır. Belirtilen bu sistematik derleme çalışmasında, sağlık profesyonelleri ve diyabeti olan birey ile iş birliği içinde gerçekleştirilen DÖYE'nin: bireysel eğitim, grup eğitimi, bireysel ve grup eğitimi birleşimi ve uzaktan yöntemler ile çevrimiçi ya da telefonla 
yapılan eğitim olmak üzere dört şekilde yürütüldüğü rapor edilmiştir. Eğitimlerin ise hekim, sertifikalı diyabet eğitimcisi, diyetisyen, egzersiz fizyoloğu, lisanslı hemşire, eczacı, fizyoterapist, mesleki terapist, psikolog ve sosyal çalışmacı gibi çok disiplinli sağlık bakım profesyonelleri ve toplum sağlığı çalışanları gibi profesyoneller tarafından sağlandığı gösterilmiştir. İncelenen girişimsel çalışmalarda DÖYE verilen müdahale ve DÖYE verilmeyen kontrol grupları için HbA1c'deki ortalama azalma sirasiyla 0.74 ve 0.17 olarak belirlenmiştir. Ayrıca grup ve bireysel eğitimlerin birleşimi şeklinde verilen eğitimlerden sonra HbA1c'de en fazla düşüş $(0,88)$ ve eğitim süresinin fazla olmasının da ( $\geq 10$ saat) $\mathrm{HbA1c}$ düzeyinde $(\% 70,3)$ önemli azalma ile ilişkili olduğu bulunmuştur. Sonuç olarak ise DÖYE'ye katılımın özellikle glisemik değerleri sürekli yüksek hastalarda (HbA1c> 9), HbA1c düzeylerinde istatistiksel olarak anlamlı bir düşüşü sağladığını gösteren güçlü verilere ulaşılmıştır. ${ }^{14} \mathrm{He}$ ve arkadaşları (2017) tarafından DÖYE'nin, T2DM hastalarının tüm nedenlere bağlı ölüm riski üzerindeki etkisini açıklamayı amaçlayan sistematik bir inceleme ve meta-analiz çalışması yapılmıştır. Çalışmada T2DM hastalarında DÖYE'yi geleneksel bakımla karşılaştıran ve en az 12 aylık bir takip süresinin ardından sonuçları bildiren 42 randomize kontrollü çalışma değerlendirilmiştir. $\mathrm{Bu}$ çalışmalarda ortalama hasta takip süresinin 1,5 yıl, diyabet öz yönetimi eğitim grubunda mortalitenin $\% 2,3$, geleneksel bakım grubunda $\% 3,1$ olduğu ve DÖYE'nin, T2DM hastalarında tüm nedenlere bağlı ölüm riskini önemli ölçüde azalttığı belirlenmiştir. Ayrıca hem çok disiplinli ekip eğitiminin hem de hemşire liderliğinde eğitimin, T2DM hastalarında mortalite riskini anlamlı şekilde azalttığ1 belirtilmiştir. Yanı sıra daha uzun takip süresine ( $\geq 1,5$ yıl) veya daha geniş örneklem büyüklüğüne ( $\geq 300)$ sahip olan çalışmaların alt grup analizleri, DÖYE'nin T2DM mortalite riskini azaltmada önemli bir etkisi olduğunu göstermiştir. Ölüm riskini azaltmada DÖYE'nin önemli etkisinde, eğitim alan hastalarla 10 saatten fazla etkileşimin olmas1, eğitimin tekrarlanması, eğitimde yapılandırılmış müfredat kullanılması ve eğitimin yüz yüze iletişim şeklinde olması gösterilmiştir. ${ }^{28}$

Belirtilen yaşam biçimi değişikliklerine uyumu değerlendirme ve kolaylaştırma teknikleri, birinci basamak hizmetlerde pratik olabilmektedir. Hasta başvuruları sırasında doktorlar, hastaların değişime hazır olup olmadıklarını değerlendirmeli ve kademeli olarak değişimi teşvik etmelidir. Hastaların tercih, inanç, tutum, beklenti ve güvenlerini dikkate almanın, onları harekete geçirmede etkili olduğu ileri sürülmektedir. Hekimin değişim çabalarına öncülük etmesi veya ekip yaklaşımının bir parçası olması herhangi bir davranış başarısı hakkında soru sormaya zaman ayırması ve övgüde bulunması, çabayı sürdürmede güçlü motive ediciler olabilmektedir. ${ }^{19}$ Endülüs, İspanya'da eğitim düzeyi düşük T2DM'li hastalarda diyabet öz yönetimini geliştirmede hasta-hekim iletişimine dayalı bir müdahalenin standart bakımdan daha etkili olup olmadığını belirlemek amacıyla, iki ayrı birinci basamak kurumunda dokuz aile hekimi ve 184 hastanın katıldığı 12 ay süreli, pragmatik küme randomize kontrollü bir çalışma yürütülmüştür. Müdahale grubundaki hekimler, iletişim becerileri ve glisemik kontrolü izlemek ve hastalara geri bildirim sağlamak için bir araç kullanmak konusunda eğitim almış, kontrol grubu ise standart bakıma devam etmiştir. Yapılan çok düzeyli analizde, HbA1c düzeylerinin 12 ayda iki grupta da azalmakla birlikte, müdahale grubunda istatistiksel olarak daha fazla bir iyileşme gösterdiği (gruplar arasında $\mathrm{HbA1c}$ fark1 = 0,16), dislipidemi, kan basıncı, beden kitle endeksi ve bel çevresi yönünden ise gruplar arasında anlamlı fark gözlenmediği sonucuna varılmıştır. ${ }^{29}$

Bazı ülkelerde birinci basamak sağlık kurumları, kademeli olarak aile hekimi liderliğindeki yönetimden hemşire liderliğindeki ekip yönetimin (HLEY) geçmiş ve bu durum hasta sonuçlarını etkili bir şekilde iyileştirmiştir. Hollanda'da birinci basamakta T2DM yönetiminin uygulama hemşirelerince güvenli bir şekilde yapılıp yapılmadığını değerlendirmek üzere randomize kontrollü yürütülen bir çalışmada, hemşirelik girişimden sonra HbAlc'de azalma olduğu, kan basınc1 ve lipit profiline göre gruplar arası farklılıkların anlamlı olmadığ hastaların aile hekiminden ziyade hemşireler tarafından verilen hastalı yönetimi uygulamalarından daha fazla memnun kaldığ bildirilmiştir. ${ }^{30}$ Doktor liderliğindeki diyabet ekip yönetimi, hastalıkların tanı ve tedavisine daha fazla odaklanmaktadır. Ancak ağır iş yükü ve az sayıda olan aile hekimi arasındaki dengesizlikten dolayı kötü diyabet yönetimi sonuçlarına yol açan aile ziyaretleri, telefon takipleri ve sağlık eğitimine ise daha az zaman ayırmaktadır. Çin'de T2DM hastalarının öz yönetimini arttırmak için, hemşire liderliğindeki ekip yönetimi (HLEY) müdahalesinin uygulanabilirliğini ve etkinliğini randomize kontrollü olarak inceleyen bir çalışma yapılmıştır. HLEY müdahalesi, müdahalenin içeriği, sıklığı ve programlanmasına ilişkin olarak araştırmacılar, diyabet uzmanları, toplum sağlığı hekimleri ve hemşireleri, beslenme uzmanı, hastalar ve aileler ile iletişim içinde tasarlanıp planlanmıştır. Ekip, toplum sağlığı hemşireleri ve hekimleri, bir uzman klinik hemşiresi, üç diyabet uzmanı, bir beslenme uzmanı ve lisansüstü eğitim yapan hemşirelerden oluşmuştur. Müdahale öncesinde ekip, diyabet uzmanlık bilgisi, diyet ve egzersiz bilgisi; takipler, sağlık eğitimi, iletişim becerileri, ilgili politika ve düzenlemeler konularında eğitilmiştir. HLEY müdahalesi diyabet bilgisini ve diyabet öz 
yönetimine uyumu arttırmayı, duygusal destek sağlamayı ve sorunları çözmeyi amaçlamıştır. Girişim 12 izlem ziyareti (20-30 dakika süreli), altı telefon takip danışmanlığı (5-10 dakika süreli), altı sağlık dersi ve altı diyabet uzmanı danışma hizmetinden oluşmuştur. On iki takip ziyareti toplum sağlığı hemşireleri ve hemşirelik yüksek lisans öğrencileri tarafından yürütülmüştür. Takip ziyaretlerinin içeriği, açlık kan şekeri ve kan basınc1 ölçümleri, ilaca uyum, olumsuz ilaç reaksiyonları, ilaçların kullanım süreleri ile birlikte hastaların diyet ve egzersizlerinin değerlendirilmesi ve hastaların durumlarına göre bireysel sağlı eğitimi ve duygusal destek sağlanmıştır. Tekrarlanan ölçüm analizi sonucunda girişim grubunun öz yönetiminin, kontrol grubuna kıyasla daha iyi olduğu, HbA1c'de altı ayda anlamlı bir fark olmadığı, 12 aylık müdahaleden sonra iki grup arasında HbAlc'de anlamlı bir fark olduğu ve müdahalenin açlık kan şekeri üzerinde önemli bir etkisi olmadığ 1 gösterilmiştir. Çalışma sonucunda HLEY'nin toplum sağlığı kurumlarında T2DM'nin yönetimine uygulanabileceği belirtilmiştir. ${ }^{5}$ Güney Kaliforniya'da ise birinci basamak hizmetlerde Iowa modeli kullanılarak T2DM'li yetişkinlerde bir kalite geliştirme projesi yürütülmüştür. $\mathrm{Bu}$ proje, hastalarda DÖYE programının HbAlc iyileştirme ve hasta memnuniyetini arttırmaya etkisini değerlendirme amacıyla yapılmıştır. Araştırmada bir hemşire uygulayıc1, 4 aylık bir sürede her bir oturumu 90 dakika süren üç DÖYE grup oturumu yürütmüştür. DÖYE programını geliştirmek için AADE yedi öz bakım davranış kılavuzu kullanılmıştır. Programdan sonra HbA1c ortalama değişiminin \%1,44 olduğu, hastaların \%20'sinin HbA1c düzeyinin \%7'nin altına düştüğü, tamamının HbA1c düzeyinin $\% 10$ düşüş gösterdiği ve programdan oldukça memnun kaldığ1 bildirilmiştir. $^{31}$

Sağlık profesyonellerinin ekip halinde sunduğu diyabet eğitimi müdahalelerinin, T2DM'li bireylerde glisemik kontrolün iyileştirilmesinde sadece hemşire tarafından ya da hemşirelik diş1 personelden sağlanan müdahaleden daha başarılı olduğu gözlemlenmiştir. Bununla birlikte, diğer sağlık profesyonelleriyle birlikte çalışan hemşirelerin, HbA1c düzeylerini düşürmede en etkili sağlık personeli olduğu bildirilmiştir. ${ }^{32}$ Diyabet uzmanı hemşireler iyi hasta bakımı sağlamada ve öz bakım yönetimini geliştirmede çok önemli bir konumdadır. Çeşitli bakım ortamlarında çalışan bu hemşireler, çoğu zaman bireylerin ilk temas noktasıdır ve onları diğer uzmanlık hizmetlerine yönlendirir. Hemşirelik ekibinin diyabet bakımına ilişkin rol ve sorumlulukları: davranış değişikliği ve sağlık koçluğu tekniklerini kullanarak hastalığı önleme danışmanlığı, T2DM taraması, önlenmesi ve erken tanısı, öz bakımı geliştirme, ruh sağlığı sorunlarının diyabet hastalarını nasıl etkileyebileceğinin farkındalığ hastanın beslenme gereksinimlerini değerlendirme ve karşılama, idrar ve kan şekeri izlemi, oral ve parenteral tedaviler, hipoglisemi ve hipergliseminin belirlenmesi ve tedavisi olarak belirtilmiştir. ${ }^{33}$

İran'da hemşire liderliğinde 142 T2DM'li hasta ile randomize kontrollü olarak yürütülen bir çalışmada, girişim grubundaki hastalar rutin tedavi ile birlikte hemşire liderliğinde 12 hafta süreli diyabet öz bakım yönetimi almıştır. Sonuç ölçümleri başlangıçta ve randomizasyondan 12 ve 14 hafta sonra yapılmıştır. Buna göre girişim grubundaki hastaların HbA1c, kan basıncı, vücut ağırlığı, etkinlik ve sonuç beklentisi ve diyabet öz yönetim davranışlarında önemli iyileşmeler olduğu bildirilmiştir. Sonuç olarak hemşire liderliğindeki bir müdahalenin faydalı etkisinin, araştırmanın sona ermesinin ardından klinik, yaşam biçimi ve ruhsal toplumsal sonuçlar yönünden devam ettiği çıkarımında bulunulmuştur. ${ }^{34}$ Hemşire liderliğindeki DÖYE'nin kan şekeri kontrolü ve kardiyovasküler risk etkenleri üzerindeki etkisini belirlemek amaciyla 34 randomize kontrollü araştırmanın meta analizi çalışmasında da, eğitim programlarından sonra HbA1c $(\% 0,70)$ düzeyinde anlamlı düşüşler rapor edilmiş, iyi glisemik kontrolü olanlarda ve özellikle erkek hastalarda kardiyovasküler risk etkenlerinde iyileşmelerle ilişkisi gösterilmiştir. ${ }^{35}$ Yine Avustralya'da üç ayrı yerleşim yerinde hemşire liderliğinde diyabet öz yönetimini araştırmak amacıyla yapılan pilot çalışmada, 21 hasta bir yıl boyunca kronik hastalık hemşiresi olan aynı hemşire tarafından ziyaret edilmiştir. Hastaların kilo ve bel çevreleri çalışmanın başlangıcında ve sonunda ölçülmüş ve hastalara ilaç, diyet, kilo verme ve egzersizle ilgili önerilerde bulunulmuştur. Klinik bulgular, girişimlerden sonra $\mathrm{HbA1c}$ düzeylerinde anlamlı düşüşler olduğunu göstermiş ve hastalar hemşirelere güvendiklerini ve onların önerileri sayesinde bu sonuçlara ulaştıklarını bildirmişlerdir. ${ }^{36}$

Türkiye'de Sağlık Bakanlığg tarafından yayınlanan Hemşirelik Yönetmeliğinde Değişiklik Yapılmasına Dair Yönetmelik (2011) ile Diyabet Eğitim Hemşiresinin görev, yetki ve sorumlulukları arasında "diyabetli bireylerin bakımında görev alır, bireyi yaşam kalitesini yükseltmede her aşamada destekler ve gereksinim duyulan konularda danışmanlık yapar. Diyabetli bireyin kendi kendini yönetimine destek olur" yer almaktadır. ${ }^{37}$ Türkiye'de hemşire araştırmacılar tarafindan yapılan çalışmalarda da diyabet öz yönetimi eğitim programlarının olumlu sonuçları gösterilmiştir: Olgun ve Altun (2012) tarafından Sağlık İnanç Modeli (SİM) doğrultusunda verilen eğitimin diyabet hastalarının, kendi kendilerine yaptıkları bakım uygulamalarına etkisini değerlendirmek amacıyla yaptıkları çalışmada, girişim grubundaki hastalara bireysel ve grup eğitimleri ve telefon 
danışmanlığı şeklinde eğitim verilmiştir. Eğitimden sonra girişim grubundaki hastaların metabolik kontrol sonuçları, sağlık inançları ve diyabet bakımı ile ilgili öz etkililiklerinin iyileştiği bildirilmiştir. ${ }^{38}$ Eroğlu (2017)'nun T2DM'li hastalarda randomize kontrollü olarak yaptığı çalışmada, diyabet eğitimi ve eğitim kitapçı̆̆ 1 verildikten sonra girişim grubundaki hastaların diyabet öz yönetimi, öz etkililikleri ve metabolik değerlerinin anlamlı düzeyde iyileştiği gösterilmiştir. ${ }^{39}$

Aile hekimliği disiplini ilkelerine ve aile hekimliği uygulama yönetmeliğine göre aile hekimleri birinci basamakta kronik hastallkların korunması, tanı ve tedavisinde aktif görev almalıdırlar. ${ }^{40,41} \mathrm{Bu}$ çerçevede diyabet öz yönetiminde hem eğitici hem de uygulayıcı olarak görevleri vardır. Ancak Türkiye'de aşağıda belirtilen nedenlerle bu görevler beklenen düzeyde yapılamamaktadır:

- Aile hekimliği uzmanlığı tercihleri ve üniversitelerdeki aile hekimliği anabilim dallarında öğretim üyesi sayısı yetersizdir. ${ }^{42}$ Türkiye'de ortalama 24.082 aile hekimi ve aile hekimliği birimlerinde çalışan 1.814 aile hekimliği uzmanı bulunmaktadır. ${ }^{43}$ Başka bir ifadeyle aile hekimlerinin yalnızca $\% 7,5^{\prime} i$ aile hekimliği uzmanlık eğitimini tamamlamıştır. $\mathrm{Bu}$ durum ise bilgi ve tecrübe kısıtlılığına neden olmaktadır.

- Aile Hekimliği Uygulama Yönetmeliğinde Değişiklik Yapılmasına Dair Yönetmelik (2017) ile aile hekimi/aile sağlığı elemanı pozisyonlarının tespitinde "Aile hekimliği birimleri bölgede ortalama 2.000 kişiye bir aile hekimi düşecek şekilde tespit edilir" ifadesi yer almaktadır. ${ }^{44}$ Ancak aile hekimlerinin kendisine kayıtlı ortalama nüfusları 3.408 dolayındadır. ${ }^{43} \mathrm{Bu}$ da aşırı yük oluşturmakta ve kronik hastalıklarda izlem ve tarama için gerekli zamanı kısıtlamaktadır.

- Sağlık uygulama tebliğinde (SUT) aile hekimlerinin kronik hastalı yönetimindeki yetkilerinde kısitlılıklar bulunmaktadır. ${ }^{45}$

\section{Diyabet öz yönetim programları}

Diyabetli bireylerde sağlık hizmetlerinin çoğu aile hekimliği uygulaması kapsamında gerçekleştirilmekte, ancak bu hastalara yardımcı olmada zamanı ve kaynakları dengeleme zor olabilmektedir. Hastaları güçlendiren, toplum kaynaklarından yararlanan ve öz yönetime yardımcı olan bir müdahale, hasta ve çalışanlara fayda sağlayabilir. Hamilton, Ontario, Kanada'da elektronik tıbbi kayıt ile desteklenen McMaster Aile Sağlık Ekibi'nin onayladığı ardışık, açıklayıcı ve nitel bileşenlerden oluşan pilot randomize kontrollü bir çalışma yürütülmüştür. Dört ay devam eden çalışma, birinci basamak hizmetlerde diyabet ve hipertansiyon tanısı almış hastalarla yapılmıştır. Hastalar rastgele girişim $(n=15)$ ve kontrol $(n=20)$ grubuna ayrılmıştır. Girişim grubundaki hastalar, diyabet öz yönetimini destekleyen bir yaklaşım olarak Hasta Deneyimini Geliştiren Diyabet Yönetiminde Sağlık Çalışanlarıyla Kaliteyi Güçlendiren Sağlık Ekipleri (Health TAPESTRYHC-DM) tarafından sağlanan sağlık hizmeti almış, kontrol grubundaki hastalar ise rutin tedaviye devam etmiştir. $\mathrm{Bu}$ sağlık ekip yaklaşımı, hastaların öncelikli sağlık hedefleri ve gereksinimleri ile birlikte toplum gönüllülerini, e-sağlık teknolojilerini, çok disiplinli birinci basamak ekiplerini ve sistem ulaşımını bütünleştirmeye odaklanmış, diyabet ve diğer kronik durumların öz yönetiminde yeterlik geliştirmeyi amaçlamıştır. Her bir hasta, eğitimli toplum gönüllüsü "sağlık çalışanı" ile eşleştirilmiştir. Yerel bir toplum gönüllü kuruluşu tarafından istihdam edilen sağlık çalışanları, programın uygulanması ile kanıta ve sağlık profesyonellerinin görüşüne dayanarak geliştirilen eğitim el kitabı, yüz yüze ve çevrimiçi eğitimi kapsayan standart çok şekilli eğitim programı aracılığıyla, program ekibi tarafından eğitilmiştir. Gönüllüler ev ziyaretleri, telefon görüşmeleri ve elektronik mesajlar yoluyla hastalarla etkileşime geçmiştir. Dört ay sonunda kontrol grubuna göre girişim grubunda fiziksel aktivite başta olmak üzere, birçok sonucun daha iyi olduğu belirlenmiştir. Belirlenen en yaygın amaç alanlarının fiziksel aktivite, diyet/beslenme ve toplumsal etkileşim olduğu bulunmuştur. Hastalar, girişimin en büyük etkisinin hedefe ulaşma yönünde motivasyon sağladığını düşünmüş, bazı hastalar ise programın uygun olmadığını, diyabeti zaten iyi yönettiklerini ifade etmişlerdir. Çalışma sonucunda potansiyel olarak kullanılmayan çoklu kaynaklar sunan çeşitli toplum programlarının, sağlıklı yaşam biçimi öz yönetimini desteklemede önemli olabileceği ve toplum temelli sağlık ve toplumsal hizmet programlarına erişimde farkındalığın arttırılması ile hasta bakımının geliştirilebileceği vurgulanmıştır. ${ }^{2}$

Diyabet yönetiminde hasta eğitimi, olumlu öz yönetim davranışlarını geliştirmek ve desteklemek amaciyla çeşitli şekillerde verilebilmektedir. ${ }^{46}$ Internet tabanlı bilgisayar programları, kan şekeri izleme sistemleri, kısa metin mesajları ve mobil uygulamalar gibi teknolojiler, glisemik kontrolü iyileştirmek amacıyla öz yönetimi desteklemek için kullanılabilmektedir. ${ }^{24}$ Tip 2 diyabetli bireylerde grup temelli müdahalelerin bireysel müdahalelerle veya geleneksel bakımla karşılaştırıldığında, klinik, yaşam tarzı ve ruhsal toplumsal sonuçların iyileştirilmesine yönelik etkinliğini belirlemeyi amaçlayan sistematik derleme çalışması yapılmıştır. Çalışmada grup temelli eğitim müdahalelerinin kan şekeri, vücut 
ağırlığ 1 , bel çevresi, trigliserit düzeyleri, diyabet bilgisi, yaşam tarzı ve ruhsal toplumsal sonuçların iyileştirilmesinde rutin bakım ve bireysel eğitimden daha etkili olduğu bulunmuştur. Yan 1sıra tek bir disiplin, multidisipliner ekipler veya akran destekçileri olan sağlık profesyonellerinin sağladığ1 müdahalelerin, HbAlc'de akran öncülüğünde yapılan müdahalelere kıyasla daha iyi sonuçlar verdiğini göstermiştir. ${ }^{46}$ Mohamed ve arkadaşları (2019) tarafından Asya Batı Pasifik bölgesinde, T2DM'li bireylere yüz yüze verilen eğitimsel ve/veya ruhsal DÖYE müdahalelerinin uygulandığ1 21 randomize kontrollü ve karşılaştırmalı çalışmanın (yarısı yüksek yoğunluklu grup temelli çalışma) etkinliğini değerlendiren sistematik bir inceleme çalışması, sekiz çalışmanın glisemik kontrol ve HbAlc düzeylerinde iyileşmede etkili olduğunu bildirmiştir. Sonuçlar ayrıca, grup temelli DÖYE'nin iyileşen klinik ve ruhsal toplumsal sonuçlarla ilişkili olduğunu; katılımeı oturumlar ve daha uzun etkileşim süreli davranışsal kuramla desteklenen girişimlerin, bu tür programların potansiyel faydalarını en üst düzeye çıkarabileceğini göstermiştir. Yapılacak araştırmalar için, girişimlerin problem çözme ve hedef belirlemeyi içeren psikolojik yöntemler ve katılımcı oturumlarla yürütülmesi, davranış değişikliği ve baş etme becerilerinin ilave sonuç ölçümlerinin ve maliyet etkinliği analizinin yapılması ve kültürel olarak ilgili materyallerin kullanılması önerilerinde bulunulmuştur. ${ }^{47}$

İran'da tanımlayıcı fenomenolojik türde yapılan bir çalışmada ise endokrinoloji ve diyabet merkezinde yerel bir DÖYE programına katılan diyabet hastalarının program hakkındaki deneyimleri yapılandırılmamış görüşmelerle tespit edilmiştir. Katılımcıların deneyimleri, diyabet eğitiminin içeriği (yararlı ve tekrarlayan, yoğun ve geçici), öğretim yöntemleri (geleneksel, teknoloji olmadan) ve öğrenme ortamı (arkadaşça, sıkışık ve karanlık ortam) olmak üzere üç ana konuda sınıflandırılmıştır. Görüşmeler sonucunda hastalar, DÖYE'nin gereksinim ve beklentilerini karşılamadığını ifade etmişlerdir. Sonuç olarak çalışmada, gereksinim değerlendirmesi, etkileşimli öğretim yöntemleri, çok disiplinli yaklaşım, teknoloji ve uygun fiziksel alanın DÖYE'yi geliştirmede göz önünde bulundurulması gereken unsurlar olduğu belirtilmiştir. ${ }^{48}$

Etkili öz yönetim programları ile hastalara çeşitli temel becerilerin öğretilmesi beklenmektedir:

Problem çözme: Öz yönetim probleme dayalı olduğu için problem çözme, temel bir öz yönetim becerisidir.

Karar verme: Yeterli ve uygun bilgiye sahip olma üzerine temellenir ve kronik hastalığ bireylerin, hastalık durumlarına yanıt olarak günlük kararlar almasını gerektirir.

Kaynak kullanımı: Hastalara kaynakları nasıl etkili kullanabilecekleri öğretilmelidir. Yalnızca bir kaynaktan bilgi almak yerine, mümkün olduğunca çok kaynaktan gelen bilgileri almak daha iyidir.

Hasta-sağlık profesyoneli ilişkisi: Hasta, sağlık profesyonelleri ile ilişkiler kurabilme becerisine sahip olmalıdır. Hastanın rolü, hastalığın seyrini ve gidişatını bildiren ve tedaviyle ilgili bilgiye dayalı kararlar veren ve bunları sağlık hizmeti ile tartışan bir paydaş olmaktır.

Harekete geçme: Harekete geçmenin en önemli yönü, kısa vadeli bir eylem planı yapmak ve uygulamaktır. ${ }^{49}$

Kanıta dayalı diyabet öz yönetim programlarının daha etkili ve erişilebilir hale getirilmesi için sağlığın sosyal belirleyicileri de dikkate alınmalıdır. Kültürel inançlar, öz denetim ve düşük sağlık okuryazarlığı, sınırlı kaynaklara sahip bireylerde diyabet öz yönetimini etkilemektedir. Meksika'da birinci basamak kliniklerde T2DM'li yetişkinler ve sağlık çalışanları tarafından algılanan T2DM öz yönetiminde zorlukları belirlemek amacıyla yarı yapılandırılmış görüşmelerle nitel tanımlayıcı türde bir çalışma yürütülmüştür. Görüşme soruları hemşirelik, halk sağlığı, sağlık hizmetleri ve sağlık sistemi konularında uzman, çok disiplinli bir ekip tarafından işbirliği içinde geliştirilmiştir. Görüşmelerde bireysel zorluklar arasında kültürel inançlar, kaynak eksikliği, yaşam tarzı değişikliğinde zorluklar, aile desteği/yoğun talep eksikliği ve ruhsal sağlık sorunları; sistem düzeyinde ise kaynak eksikliği, algılanan bakım kalitesi ve hasta katılım engellerinin yer aldığ 1 belirlenmiştir. $^{50} \mathrm{Bu}$ bağlamda kapsamlı diyabet yönetimi eğitim programlarına okuryazarlığa ve sayısallığa duyarlı materyaller eklemek, özellikle okuryazar düzeyi düşük bireylerde bilgi, öz yeterlilik ve HbA1c sonuçlarını iyileştirmede etkili olabilir. ${ }^{24}$

\section{SONUÇ}

Bu çalışmada Türkiye ve yabancı ülkelerde özellikle birinci basamakta aile hekimi ve hemşire liderliğinde yürütülen birçok çalışma ile, diyabet öz yönetim müdahalelerinin yararlı etkileri olduğuna dair kanıtlar gösterilmiştir. Öz yönetim eğitimi ve desteği, diyabet bakımının temel bir bileşenidir. Hastaların ve sağlık çalışanlarının kültürel inançları ve diyabete yönelik tutumları göz önünde bulundurularak, diyabet öz yönetim eğitimi ve desteğinin sağlık hizmetleri ile bütünleştirilmesi, klinik sonuçlarda iyileşme sağlaması yönünden önemlidir ve bu müdahale programları çok disiplinli 
ekibin katılımı ile düzenlenmeli ve sürdürülmelidir. $\mathrm{Bu}$ bağlamda öz yönetim eğitimi ve destek programlarının geliştirilmesi, erişilebilir olması acil ve önemli bir gereksinimdir.

\section{KAYNAKLAR}

1. Bilir N, Erbaydar NP. Bulaşıcı olmayan hastalıklar ve kontrolü. Halk Sağlığı Temel Bilgiler 3. Edit: Güler Ç, Akın L. Hacettepe Üniversitesi Yayınları, 3. Baskı- Tıpkı Basım, Ankara, 2015; s: 1550-1551.

2. Agarwal G, Gaber J, Richardson J, Mangin D, Ploeg J, Valaitis R, et al. Pilot randomized controlled trial of a complex intervention for diabetes selfmanagement supported by volunteers, technology, and interprofessional primary health care teams. Pilot and Feasibility Studies 2019; 5:1-16.

3. Cho NH, Shaw JE, Karuranga S, Huang Y, Fernandes JDR, Ohlrogge AW et al. IDF Diabetes Atlas: global estimates of diabetes prevalence for 2017 and Projections for 2045. Diabetes Res Clin Pract. 2018;138:271-281.

4. Diabetes Self-Management Report. Georgia Department of Public Health, 2013. https://ph.georgia.gov/sites/dph.georgia.gov/f iles/DiabetesSelfManagement_WebVersion.pd f Erişim: 05.11.2019.

5. Guo Z, Liu J, Zeng H, He G, Ren X, Guo J. Feasibility and efficacy of nurse-led management intervention for improving the self-management of type 2 diabetes patients in a Chinese community: a randomized controlled trial. Patient Prefer Adherence. 2019;13:13531362.

6. IDF Diabetes Atlas. $9^{\text {th }}$ Edition, 2019. https://www.diabetesatlas.org/en/sections/worl dwide-toll-of-diabetes.html Erişim: 04.11.2019.

7. Satman I, Omer B, Tutuncu Y, Kalaca S, Gedik S, Dinccag N, et al. TURDEP-II Study Group. Twelve-year trends in the prevalence and risk factors of diabetes and prediabetes in Turkish adults. Eur J Epidemiol. 2013;28:169-80.

8. Davies MJ, D'Alessio DA, Fradkin J, Kernan WN, Mathieu C, Mingrone G, et al. Management of hyperglycaemia in type 2 diabetes, 2018. A consensus report by the American Diabetes Association (ADA) and the European Association for the Study of Diabetes (EASD). Diabetologia 2018;61:2461-2498.

9. Kousoulis AA, Patelarou E, Shea S, Foss C, Ruud Knutsen IA, Todorova E, et al. Diabetes self management arrangements in Europe:a realist review to facilitate a Project implemented in six countries. BMC Health Serv Res. 2014;14:1-18.

10. Ross J, Stevenson FA, Dack C, Pal K, May CR, Michie S, et al. Health care professionals' views towards selfmanagement and selfmanagement education for people with type 2 diabetes. BMJ Open. 2019;9(7):e029961, 111.

11. Carpenter R, DiChiacchio T, Barker K. Interventions for self-management of type 2 diabetes: An integrative review. Int J Nurs Sci. 2018;6(1):70-91.

12. Bodenheimer $T$, Macgregor $K$, Sharifi $C$ : Helping patients manage their chronic conditions. Oakland, CA, California Health Care Foundation, 2005. https://www.chcf.org/wpcontent/uploads/2017/12/PDF-Helping Patients Manage Their Chronic Conditions.pdf. Erişim: 24.02.2020

13. Hinder S, Greenhalgh T. "This does my head in". Ethnographic study of self-management by people with diabetes. BMC Health Serv Res.2012;12:1-16.

14. Chrvala CA, Sherr D, Lipman RD. Diabetes self-management education for adults with type 2 diabetes mellitus: A systematic review of the effect on glycemic control. Patient Educ Couns.2016; 99:926-43. (Erişim: 05.11.2019).

15. American Diabetes Association, 4. Foundations of care: education, nutrition, physical activity, smoking cessation, psychosocial care, and immunization, Diabetes Care 2015; 38 (Supplement 1): S20-S30.

16. Kourakos MI, Enhancing self-management in diabetes: the value of therapeutic education. IJHSR 2017; 7:315-21.

17. Al Johani KA, Kendall GE, Snider PD. Self management practices among type 2 diabetes patients attending primary healthcare centres inMedina,Saudi Arabia. East Mediterr Health J. 2015;21(9):621-8.

18. Coyle ME, Francis K, Chapman Y. Selfmanagement activities in diabetes care: a systematic review. Aust Health Rev. 2013; 37(4):513-22.

19. Koenigsberg MR, Corliss J. Diabetes selfmanagement: facilitating lifestyle change. Am Fam Physician. 2017;96(6):362-370.

20. S Van den Broucke, GH Van der Zanden and the Diabetes Literacy consortium. Diabetes literacy. Enhancing the effectiveness of diabetes self-management education. Final report. Louvain-la-Neuve: Université catholique de Louvain, 2016. https://cordis.europa.eu/docs/results/306/30618 6/final1-diabetesliteracyfinal.pdf Erişim: 01.11.2019.

21. Haas L, Maryniuk M, Beck J, Cox CE, Duker P, Edwards L, et al. National standards for diabetes self-management education and support. Diabetes Educ. 2012;38:619-29.

22. Powers MA, Bardsley J, Cypress M, Duker P, Funnell MM, Fischl AH, et al. Diabetes self management education and support in type 2 
diabetes: A Joint Position Statement of the American Diabetes Association, the American Association of Diabetes Educators, and the Academy of Nutrition and Dietetics. J Acad Nutr Diet. 2015;115:1323-34.

23. Funnell MM, Brown TL, Childs BP, Haas LB, Hosey GM, Jensen B, et al. National Standards for Diabetes Self-Management Education. Diabetes Care. 2011; 34(Suppl 1): S89-S96.

24. Sherifali D, Berard LD, Gucciardi E, MacDonald B, MacNeill G. SelfManagement Education and Support. Diabetes Canada Clinical Practice Guidelines_Expert Committee. Can J Diabetes. 2018;42 Suppl 1:S36-S41.

25. Azami G, Soh KL, Sazlina SG, Salmiah MS, Aazami S. Behavioral interventions to improve self-management in Iranian adults with type 2 diabetes: a systematic review and metaanalysis. J Diabetes Metab Disord. 2018;17:365-380.

26. Cani CG, Lopes LS, Queiroz M, Nery M. Improvement in medication adherence and selfmanagement of diabetes with a clinical pharmacy program: a randomized controlled trial in patients with type 2 diabetes undergoing insulin therapy at a teaching hospital. Clinics. 2015;70:102-106.

27. Okuroğlu GK, Alpar ŞE. Diyabette web tabanlı uzaktan eğitim: online diyabet eğitim programı örneği. Turkiye Klinikleri J Intern Med NursSpecial Topics 2015;1(3):24-30.

28. He X, Li J, Wang B, Yao Q, Li L, Song R, et al. Diabetes self-management education reduces risk of all-cause mortality in type 2 diabetes patients: a systematic review and meta-analysis. Endocrine 2017;55:712-731.

29. Olry de Labry Lima A, Bermúdez Tamayo C, Pastor Moreno G, Bolívar Muñoz J, Ruiz Pérez I, Johri M. Effectiveness of an intervention to improve diabetes selfmanagement on clinical outcomes in patients with low educational level. Gac Sanit. 2017;31:40-47.

30. Houweling ST, Kleefstra N, van Hateren KJ, Groenier KH, Meyboom-de Jong B, Bilo HJ. Can diabetes management be safely transferred to practice nurses in a primary care setting? A randomised controlled trial. J Clin Nurs. 2011;20:1264-72.

31. Peros J, James K, Nolan S, Meyerhoff B. Diabetes Self-Management Education (DSME) program for glycemic control. Integr Obesity Diabetes 2016; 2: 239-244.

32. Klein HA, Jackson SM, Street K, Whitacre JC, Klein G. Diabetes self-management education: miles to go. Nurs Res Pract. 2013; 2013:1-15.

33. Royal college of nursing /clinical /diabetes /education, prevention and the role of the nursing team. https://www.rcn.org.uk/clinicaltopics/diabetes/education-prevention-and-therole-of-the-nurse. Erişim: 01.11.2019.

34. Azami G, Soh KL, Sazlina SG, Salmiah MS, Aazami S, Mozafari M, et al. Effect of a nurse-led diabetes selfmanagement education program on glycosylated hemoglobin among adults with type 2 diabetes. J_Diabetes Res. 2018; 2018:1-12.

35. Tshiananga JK, Kocher S, Weber C, ErnyAlbrecht K, Berndt K, Neeser K. The effect of nurse-led diabetes selfmanagement education on glycosylated hemoglobin and cardiovascular risk factors: a meta-analysis. Diabetes_Educ. 2012;38:108-23.

36. Kirby S, Moore M, McCarron T, Perkins D, Lyle D. Nurse-led diabetes management in remote locations. Can J Rural Med. 2015;20:515.

37. Sağlık Bakanlığı (2011) Hemşirelik Yönetmeliğinde Değişiklik Yapılmasına Dair Yönetmelik. Resmi Gazete, 27910 (19.04.2011).

38. Olgun N, Altun ZA. Sağlık İnanç Modeli Doğrultusunda Verilen Eğitimin Diyabet Hastalarının Bakım Uygulamalarına Etkisi. Hacettepe Üniversitesi Sağlık Bilimleri Fakültesi Hemşirelik Dergisi 2012; 46-57.

39. Eroğlu N. Tip 2 diyabetli hastalarda eğitimin diyabet öz yönetim ve öz etkililiklerine etkisi. Haliç Üniversitesi Sağlık Bilimleri Enstitüsü. Yayınlanmamış Doktora Tezi. İstanbul, 2017.

40. The European definitions of the key features of the discipline of general practice the role of the general practitioner and a description of the core competencies of the general practitioner / family physician. WONCA Europe 2011 Edition.

https:/sagam.at/system/files/attachments/europ ean_definition_3rd_ed_2011_with_revised_wo nca_tree.pdf (Ërişim: $1 \overline{2} .04 . \overline{2020})$.

41. Aile Hekimliği Uygulama Yönetmeliği. Resmî Gazete Tarihi: 25.01.2013 Resmî Gazete Sayıs1: 28539.

42. Türkiye Aile Hekimleri Uzmanlık Derneği (TAHUD) Kisa Raporu. 2017. https://www.tahud.org.tr/file/ac9eef0c-0749$\underline{4 d 7 b-}$ 9f4503b79672e991/THSK\%20Rapor\%20Topl am.pdf (Erişim: 12.04.2020).

43. Ungan M. Aile hekimliğinde sayı, sistem, nitelik ve eğitim. Sağlık Düşüncesi ve Tıp Kültürü Dergisi 2019; 49: 26-29.

44. Aile Hekimliği Uygulama Yönetmeliğinde Değişiklik Yapılmasına Dair Yönetmelik. 16. 05.2017. Resmi Gazete. Say1 : 30068.

45. Sosyal Güvenlik Kurumu Sağlık Uygulama Tebliği. 24.03.2013. Resmi Gazete. Sayı: 28597. 
46. Odgers-Jewell K, Ball LE, Kelly JT, Isenring EA, Reidlinger DP, Thomas R. Effectiveness of group-based self-management education for individuals with Type 2 diabetes: a systematic review with meta-analyses and metaregression. Diabet Med. 2017;34:1027-1039.

47. Mohamed A, Staite E, Ismail K, Winkley K. systematic review of diabetes self management education interventions for people with type 2 diabetes mellitus in the Asian Western Pacific (AWP) region. Nurs Open. 2019;6(4):14241437.

48. Mardanian Dehkordi L, Abdoli S. Diabetes Self-management education; experience of people with diabetes. J Caring Sci. 2017;6(2):111-118.
49. Self-Management Support: A Health Care Intervention. BC Ministry of Health. British Columbia,

2011.https://www.selfmanagementbc.ca/uploa ds/What $\% 20$ is $\% 20$ Self-

Management/PDF/SelfManagement\%20Suppo $\mathrm{rt} \% 20 \mathrm{~A} \% 20$ health $\% 20$ care $\% 20$ intervention $\% 2$ 02011.pdf Erişim: 06.11. 2019

50. Whittemore R, Vilar-Compte M, De La Cerda $\mathrm{S}$, Marron D, Conover R, Delvy R, et al. Challenges to diabetes self-management for adults with type 2 diabetes in low-resource settings in Mexico City: a qualitative descriptive study. Int $J$ Equity Health. 2019;18(1):133. 